\title{
Inhibition of ovarian function in subordinate female marmoset monkeys (Callithrix jacchus jacchus)*
}

\author{
D. H. Abbott $\dagger$, A. S. McNeilly, S. F. Lunn, M. J. Hulme and F. J. Burden $\ddagger$ \\ M.R.C. Reproductive Biology Unit, Centre for Reproductive Biology, 37 Chalmers Street, \\ Edinburgh EH3 9EW, U.K.
}

\begin{abstract}
Summary. Plasma concentrations of progesterone, cortisol, $\mathrm{LH}$ and prolactin were measured in dominant and subordinate female marmosets in 10 well-established peer groups. Subordinate females never ovulated, had a reduced LH response to LH-RH and showed no positive feedback LH surge after oestrogen administration. There was no evidence of elevated plasma cortisol levels or hyperprolactinaemia in subordinates and all showed a similar prolactin response to TRH in comparison with dominants. However, subordinates showed a reduced prolactin response to metoclopramide. These results clearly indicate that high circulating levels of cortisol or prolactin are not responsible for the inhibition of ovulation in female marmosets.
\end{abstract}

\section{Introduction}

Prolactin release in response to specific or non-specific stress has been reported for many mammalian species (Raud, Kiddy \& Odell, 1971; Horrobin, 1973; Lamming, Moseley \& McNeilly, 1975; McNeilly, 1980). Elevated prolactin levels (hyperprolactinaemia) have also been linked with the inhibition of reproductive function (high-prolactinamenorrhoea) in women (Besser, Parke, Edwards, Forsyth \& McNeilly, 1972; Tyson, Friesen \& Anderson, 1972; Van Look, McNeilly, Hunter \& Baird, 1977; Baird, McNeilly, Sawers \& Sharpe, 1979) and in captive subordinate female talapoin monkeys, Miopithecus talapoin (Bowman, Dilley \& Keverne, 1978; Keverne, 1979). In both cases, high prolactin concentrations were clearly associated with the inhibition of the ovulatory surge of pituitary $\mathrm{LH}$ in response to oestrogen. It was proposed by Bowman et al. (1978) and Keverne (1979) that in talapoin monkeys, increased prolactin values were due to the stress of attacks from dominant females. However, in these studies only two captive groups of talapoin monkeys were used, "only the most dominant and subordinate individuals" were compared, and it was not established how frequently high prolactin levels were associated with behavioural subordination and infertility in females. As acknowledged by Bowman et al. (1978), not all subordinate female talapoin monkeys are normally infertile because these animals are polygamous (Rowell \& Dixson, 1975). Furthermore, all the females were ovariectomized and blood oestrogen levels were maintained by implants of oestradiol-17 $\beta$.

In the present study, 10 groups of captive marmoset monkeys (Callithrix jacchus jacchus) were used and the females were left intact. Marmosets are monogamous (Epple, 1967; Rothe, 1975; Stevenson, 1978) and only the single dominant female in any group reproduces because the subordinates do not ovulate (Abbott \& Hearn, 1978). We investigated whether (1) the

* Reprint requests to Dr A. S. McNeilly.

† Present address: University of Cambridge, Department of Anatomy, Downing Street, Cambridge CB2 3DY, U.K.

‡ Present address: Inveresk Research Institute, Inveresk, East Lothian, Scotland, U.K. 
ovarian inhibition of subordinate female marmosets was associated with increased peripheral prolactin concentrations, and (2) a pituitary LH surge in these infertile animals could be elicited similar in magnitude and duration to that occurring at ovulation in normal cyclic females (Hodges \& Hearn, 1977).

\section{Materials and Methods}

The animals and their management have been described elsewhere (Hearn, Lunn, Burden \& Pilcher, 1975).

\section{Peer groups and behavioural status}

Ten peer groups were formed, each consisting of 3 male and 3 female post-pubertal marmosets (Abbott \& Hearn, 1978). Dominant or subordinate status was assigned on the basis of an animal's aggressive and submissive interactions with others in the group (Abbott \& Hearn, 1978; Abbott, 1979). In each group, the dominant male (Male 1) and the dominant female (Female 1) rapidly established a pair bond (Abbott \& Hearn, 1978; Abbott, 1979). The subordinate or second and third ranking males (Males 2 and 3, respectively) and subordinate females (Females 2 and 3 ) formed no such social or sexual relationship with any animal in the group (Abbott, 1978, 1979). In 7 out of the 10 groups, one of the subordinate females had to be removed after the first 2-3 days because of persistent attacks from an animal of higher rank, as previously found (Abbott, 1978, 1979).

\section{Blood sampling and hormone assays}

Blood samples of $0.3 \mathrm{ml}$ were withdrawn from the femoral vein into a heparinized syringe through a $0.41 \mathrm{~mm}$ diameter needle ( 27 gauge). Sampling was carried out between 09:30 and $12: 30 \mathrm{~h}$. The females were held in a restraining device and were not anaesthetized (Hearn, 1977). All samples were taken 2-4 min after removal of the animals from their cages and then immediately placed on ice. The blood was centrifuged at $500 \mathrm{~g}$ for $20 \mathrm{~min}$ at $4{ }^{\circ} \mathrm{C}$ and the plasma stored at $-20^{\circ} \mathrm{C}$ until assayed. Females were bled at 2-3-day intervals for 6 months, starting 5-12 months after the peer groups had been established. The frequency of sampling was sufficient to cover the approximately 10-12-day period of plasma progesterone elevation during the luteal phase of the 16-17-day ovarian cycle (Hearn \& Lunn, 1975). Plasma prolactin and cortisol concentrations were estimated from samples 2-20 days apart.

\section{Hormone assays}

Plasma concentrations of progesterone (Chambers \& Hearn, 1979), LH (Hodges, 1978), chorionic gonadotrophin (Chambers \& Hearn, 1979) and prolactin (McNeilly, Abbott, Lunn, Chambers \& Hearn, 1981) were determined by specific radioimmunoassays validated for use in the marmoset monkey. All samples were assayed in duplicate. Plasma cortisol was measured using a competitive protein-binding kit (Cortipac; The Radiochemical Centre, Amersham, U.K.) and cross-reactions with other steroids and corticosteroids have been described (Technical Bulletin $75 / 10)$. No significant departure from parallelism between the human standards $(2-47 \cdot 8$ $\mu \mathrm{g} / 100 \mathrm{ml})$ and serial dilutions of marmoset plasma $(1: 8-1: 128)$ was demonstrated $(P<0 \cdot 10)$ by a two-factor analysis of variance with replication. All samples were diluted to read within this range. Two pools of female marmoset plasma (diluted to $1: 20(\mathrm{v} / \mathrm{v})$ with distilled water) were used to determine the inter- and intra-assay coefficients of variation (CV). One pool was repeatedly measured in duplicate in 5 assays and gave a mean value ( \pm s.e.m.) of $100 \pm 3.5$ 
$\mu \mathrm{g} / 100 \mathrm{ml}$ with a CV between assays of $10.4 \%$. The other pool was repeatedly measured in one assay and gave a value of $99.6 \pm 3 \cdot 5 \mu \mathrm{g} / 100 \mathrm{ml}$ with a CV of $7.8 \%(n=8)$.

\section{Ovarian cycle and detection of pregnancy}

The luteal phase of each ovarian cycle was defined as lasting from the rise of plasma progesterone concentrations above $20 \mathrm{ng} / \mathrm{ml}$ until levels decreased again below that value. When plasma progesterone rises above $20 \mathrm{ng} / \mathrm{ml}$ in cyclic female marmosets, progesterone values quickly reach $50 \mathrm{ng} / \mathrm{ml}$ and more for at least 10-12 days, typical of the previously described luteal phase of the cycle (Hearn \& Lunn, 1975).

Since females were excluded from the study while pregnant, and so as not to miss any early spontaneous abortion (Abbott, 1979), pregnancies were determined by radioimmunoassay of serial plasma samples for progesterone and chorionic gonadotrophin and by monthly transabdominal uterine palpation (Hearn \& Lunn, 1975; Chambers \& Hearn, 1979).

\section{LH stimulation with $\mathrm{LH}-\mathrm{RH}$ and oestradiol benzoate}

At the end of the 6-month period of serial blood sampling, dominant and subordinate females were each given $2 \mu \mathrm{g} \mathrm{LH-RH}$ (Hoechst U.K. Ltd, Hounslow, Middlesex, U.K.) intravenously (Hodges, 1979), following an initial blood sample $(0.4 \mathrm{ml})$. The animals were bled at $30,45,60$ and 90 min thereafter. As controls, 6 dominant and 4 subordinate females received a similar volume of saline $(9 \mathrm{~g} \mathrm{NaCl} / \mathrm{l}) 3$ weeks later, and were bled after $0,30,45,60$ and $90 \mathrm{~min}$.

One month after receiving LH-RH, each dominant and subordinate female was given $35 \mu \mathrm{g}$ oestradiol benzoate (Organon Laboratories Ltd, Morden, Surrey, U.K.) in a single subcutaneous injection of arachis oil $(0.2 \mathrm{ml}$ ), and then bled after $0,8,24,28,36,48$ and $60 \mathrm{~h}$ (Hodges \& Hearn, 1978): 6 dominant and 4 subordinate females received a single injection of arachis oil 2 weeks later, as controls, and were bled similarly. A positive feedback response to an oestrogen challenge was considered to be an increase in circulating $\mathrm{LH}$ to values exceeding two standard deviations of the mean control values (Hodges \& Hearn, 1978).

\section{Prolactin stimulation with TRH and metoclopramide}

TRH ( $25 \mu \mathrm{g}$; Roche Products Ltd, London, U.K.) was given intravenously in $0.2 \mathrm{ml}$ saline to 7 dominant and 9 subordinate female monkeys at the time of LH-RH infusion, and blood samples were taken $-30,0,15,30,45,60$ and $90 \mathrm{~min}$. The same females were injected i.m. with $2 \mathrm{mg}$ metoclopramide in $0.2 \mathrm{ml}$ saline (Maxolon: Beecham Research Labs, Brentford, Middlesex, U.K.) 1 week later and blood samples were taken at $-30,0,30,60$ and 90 min. Both TRH and metoclopramide are known to raise prolactin levels in female marmoset monkeys (McNeilly et al., 1981). TRH was injected simultaneously with LH-RH since LH-RH has no significant effect on prolactin concentrations (McNeilly et al., 1981) and TRH produces no marked change in LH concentration (Hodges, 1978). As controls, 5 dominant and 5 subordinate females were given saline 4 weeks later.

\section{Analysis}

Six females were excluded from the LH-RH experiment and 1 from the oestradiol benzoate experiment because they had high progesterone levels (i.e. luteal phase or pregnant). As in other species (Fink, 1979), high progesterone concentrations inhibit LH release (J. K. Hodges, personal communication). Animals in poor condition at the time of an experiment were also excluded (see Text-figure legends for numbers included in each experiment).

The plasma cortisol and prolactin concentrations in subordinate females obtained during the 
6-month sampling period were each compared against those of the dominant female in their group by Student's $t$ test. The plasma LH concentrations after LH-RH administration, and the plasma prolactin concentrations after TRH and metoclopramide injection were all analysed by a two-way analysis of variance for repeated measures. Comparisons of individual means were made using an a posteriori Newman-Keuls test (Winer, 1962). A one-way analysis of variance for repeated measures was performed separately on values from dominant and subordinate females if a significant behavioural status-by-time sampled interaction was achieved $(P<0.05)$.

\section{Results}

\section{Progesterone and pregnancy}

The dominant female in each of the 10 groups exhibited circulating concentrations of progesterone characteristic of the follicular and luteal phases of a normal ovarian cycle (Table 1). In contrast, subordinate females had only follicular-phase concentrations of progesterone, indicating that none had ovulated. All of the dominant females subsequently became pregnant, but pregnancy was not detected in any subordinate female.

Table 1. Mean \pm s.e.m. plasma progesterone concentrations $(\mathrm{ng} / \mathrm{ml})$ in dominant and subordinate female marmosets in 10 peer groups sampled every $2-3$ days for 6 months

\begin{tabular}{|c|c|c|c|c|}
\hline \multirow[b]{2}{*}{ Group } & \multicolumn{3}{|c|}{ Dominant females } & \multirow{2}{*}{$\frac{\text { Subordinate females }}{\begin{array}{c}\text { All } \\
\text { values }\end{array}}$} \\
\hline & $\begin{array}{l}\text { Follicular } \\
\text { phase }\end{array}$ & Luteal phase & $\begin{array}{l}\text { Peak luteal } \\
\text { values }\end{array}$ & \\
\hline 1 & $4.9 \pm 1 \cdot 6$ & $78 \cdot 3 \pm 11 \cdot 0$ & $109 \cdot 1 \pm 20 \cdot 5$ & $\begin{array}{l}3.2 \pm 0.4 \\
4.4 \pm 0.7\end{array}$ \\
\hline 2 & $8 \cdot 1 \pm 2 \cdot 0$ & $91 \cdot 8 \pm 14 \cdot 1$ & $141 \cdot 2 \pm 11 \cdot 3$ & $7 \cdot 8 \pm 1.6$ \\
\hline 3 & $2.7 \pm 0.6$ & $50.7 \pm 9.8$ & $136.3 \pm 30.8$ & $2.7 \pm 0.3$ \\
\hline 4 & $6.0 \pm 0.9$ & $65 \cdot 8 \pm 3 \cdot 5$ & $101.5 \pm 13.9$ & $3.0 \pm 0.2$ \\
\hline 5 & $9 \cdot 2 \pm 2.9$ & $93.2 \pm 29.4$ & $146 \cdot 8 \pm 22 \cdot 2$ & $\begin{array}{l}6.2 \pm 2.0 \\
6 \cdot 1 \pm 2.0\end{array}$ \\
\hline 6 & $3 \cdot 6 \pm 0.4$ & $43 \cdot 9 \pm 4 \cdot 2$ & $75 \cdot 3 \pm 9 \cdot 8$ & $\begin{array}{l}3.5 \pm 0.4 \\
4.9 \pm 0.8\end{array}$ \\
\hline 7 & $3 \cdot 2 \pm 0.4$ & $59 \cdot 2 \pm 4.9$ & $97 \cdot 7 \pm 16 \cdot 6$ & $2.9 \pm 0.3$ \\
\hline 8 & $4.0 \pm 0.5$ & $47.6 \pm 4.7$ & $56 \cdot 3 \pm 5 \cdot 8$ & $3.0 \pm 0.6$ \\
\hline 9 & $7.5 \pm 1.5$ & $82 \cdot 2 \pm 7.4$ & $119.8 \pm 23.4$ & $3.9 \pm 0.4$ \\
\hline 10 & $2 \cdot 6 \pm 0.3$ & $72.6 \pm 3.7$ & $109 \cdot 9 \pm 9 \cdot 1$ & $3 \cdot 0 \pm 0 \cdot 2$ \\
\hline
\end{tabular}

\section{Cortisol}

In 2 of the 5 groups sampled, there were similar plasma cortisol concentrations in the dominant and subordinate females (Groups 7 and 9; Table 2). In Group 6, the dominant female had cortisol levels similar to those of the second-ranking female, but higher than those of the third. In the remaining 2 groups, both dominant females had cortisol levels higher than those of their respective subordinates.

\section{LH stimulation}

$L H-R H$. There was a significant difference between dominant and subordinate females in their LH responses to LH-RH $(P<0.01)$ which, because of their identical basal LH concentrations, led to a significant behavioural status-by-time sampled interaction $(P<0.001$; Text-fig. 1a). Following the LH-RH injection, plasma $\mathrm{LH}$ concentrations in dominant females were elevated by $30 \mathrm{~min}$ and rose to a peak after $45 \mathrm{~min}(P<0.001$; Text-fig. 1a). By $90 \mathrm{~min}, \mathrm{LH}$ levels were still elevated above baseline. In contrast, there was no significant elevation of plasma 
Table 2. Plasma cortisol concentrations (mean \pm s.e.m. for no. of observations in parentheses) in female marmosets from 5 peer groups

\begin{tabular}{llll}
\hline & \multicolumn{3}{c}{ Plasma cortisol $(\mu \mathrm{g} / 100 \mathrm{ml})$} \\
\cline { 2 - 4 } Group & Female 1 & Female 2 & Female 3 \\
\hline 3 & $414 \pm 76(6)$ & $285 \pm 42^{*}(8)$ & \\
6 & $184 \pm 12(16)$ & $238 \pm 50(7)$ & $88 \pm 12^{* *}(8)$ \\
7 & $189 \pm 8(14)$ & $182 \pm 17(12)$ & \\
8 & $523 \pm 69(6)$ & $320 \pm 36^{*}(8)$ & \\
9 & $190 \pm 6(10)$ & $280 \pm 55(9)$ & \\
\hline
\end{tabular}

Values significantly different from those of Female $1,{ }^{*} P<0.05,{ }^{* *} P<0.01$ (Student's $t$ test).

LH concentrations in subordinate females. Nevertheless, 2 out of the 9 subordinates tested showed LH responses equal in magnitude and duration to those of the dominant females (Text-fig. 1b).

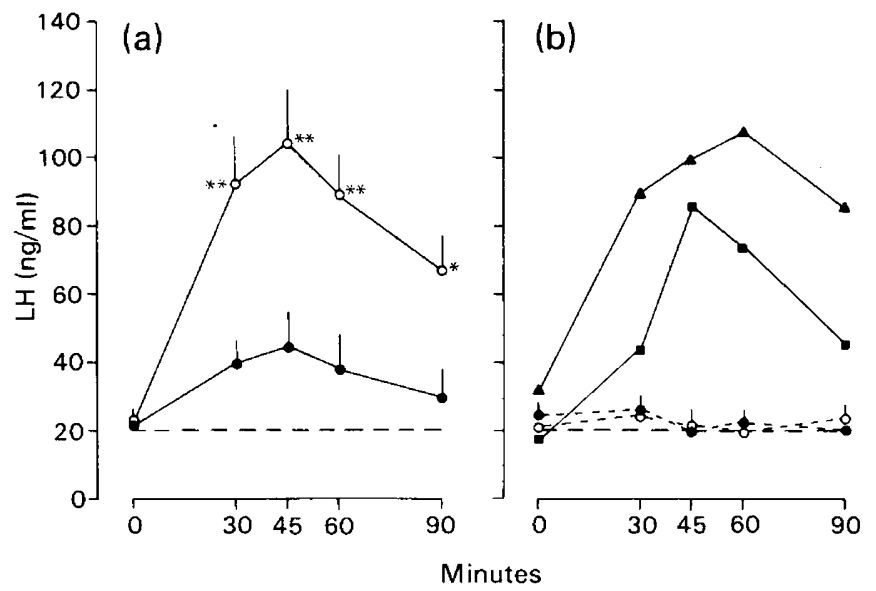

Text-fig. 1. Plasma LH concentrations (mean \pm s.e.m.) in (a) 4 dominant $(\mathrm{O}-\mathrm{O})$ and 9 subordinate (-O) female marmosets given $2 \mu \mathrm{g} \mathrm{LH}-\mathrm{RH}$ i.v. at $0 \mathrm{~min}$ and (b) 2 of the 9 subordinates responding to $2 \mu \mathrm{g} \mathrm{LH}-\mathrm{RH}(\mathbf{\Delta} ; \mathbf{D})$ and 6 dominant $(\mathrm{O}-----\mathrm{O})$ and 4 subordinate $(----)$ females given saline (at $0 \mathrm{~min}$ ). Values significantly different from those at $0 \mathrm{~min}$ : ${ }^{*} P<0.05,{ }^{* *} P<0.01$. The sensitivity limit of the assay $(20 \mathrm{ng} / \mathrm{ml})$ is shown by the broken horizontal line.

Oestradiol benzoate. The $\mathrm{LH}$ responses of dominant and subordinate females to a single injection of oestradiol benzoate are shown in Text-fig. 2. Plasma LH concentrations increased abruptly in 8 of the 9 dominant females between 8 and $24 \mathrm{~h}$ after the oestrogen injection and, in all 8 females, the criterion set for positive feedback was reached at the $24 \mathrm{~h}$ sample. The remaining animal showed a positive feedback response between 24 and $36 \mathrm{~h}$.

None of the 13 subordinate females showed any positive feedback response of LH to the oestrogen challenge: plasma LH levels remained below the sensitivity limit of the assay throughout the $60 \mathrm{~h}$ (Text-fig. 2c). These sustained low LH concentrations were not observed when subordinates were given the oil vehicle (range of individual values: $<20-43 \mathrm{ng} / \mathrm{ml}$ ). Some females in both dominant and subordinate categories also showed an inexplicable drop in plasma LH concentrations $24-36 \mathrm{~h}$ after oil administration. 

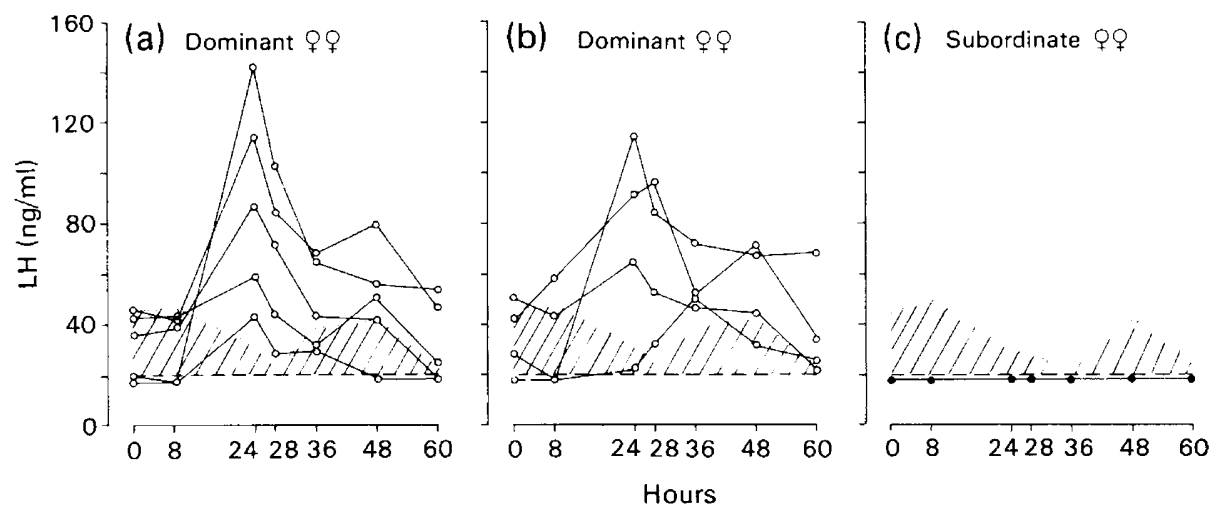

Text-fig. 2. Plasma LH concentrations in (a) 5 dominant, (b) 4 dominant, and (c) 13 subordinate female marmosets after the s.c. administration of $35 \mu \mathrm{g}$ oestradiol benzoate at $0 \mathrm{~h}$. The shaded area represents the area covered by two standard deviations from mean control values of 6 dominant females in (a) and (b) and 4 subordinate females in (c) given oil. The sensitivity limit of the assay $(20 \mathrm{ng} / \mathrm{ml})$ is shown by the broken horizontal line.

\section{Prolactin}

There were no differences in plasma prolactin levels between dominant and subordinate females in 5 out of the 10 groups (Table 3). In another 4 groups, a subordinate had circulating prolactin concentrations lower than those of the dominant animal. In the last group, the subordinate had higher prolactin levels than the dominant.

Table 3. Plasma prolactin concentrations (mean \pm s.e.m. for no. of observations in parentheses) in female marmosets from 10 peer groups

\begin{tabular}{|c|c|c|c|}
\hline \multirow[b]{2}{*}{ Group } & \multicolumn{3}{|c|}{ Plasma prolactin $(\mathrm{ng} / \mathrm{ml})$} \\
\hline & Female 1 & Female 2 & Female 3 \\
\hline 1 & $19 \cdot 6 \pm 3 \cdot 4(10)$ & $20 \cdot 8 \pm 3.4(10)$ & $8 \cdot 3 \pm 2 \cdot 0^{* *}(9)$ \\
\hline 2 & $17 \cdot 0 \pm 4.6(15)$ & $7.8 \pm 1.1^{* *}(13)$ & \\
\hline 3 & $22.0 \pm 7.5(9)$ & $11.5 \pm 1 \cdot 1^{*}(17)$ & \\
\hline 4 & $17.2 \pm 1.6(26)$ & $7.5 \pm 0.7^{* *}(25)$ & \\
\hline 5 & $13.7 \pm 1.2(18)$ & $17 \cdot 2 \pm 2 \cdot 1(17)$ & $15.2 \pm 1.8(18)$ \\
\hline 6 & $13.9 \pm 1.4(19)$ & $11.8 \pm 1.7(18)$ & $10.7 \pm 2.0(8)$ \\
\hline 7 & $15.6 \pm 2.6(15)$ & $14.3 \pm 0.6(15)$ & \\
\hline 8 & $13.4 \pm 1.7(15)$ & $11.5 \pm 2 \cdot 2(8)$ & \\
\hline 9 & $13.9 \pm 1.2(16)$ & $14.7 \pm 1.1(16)$ & \\
\hline 10 & $11.1 \pm 1 \cdot 1(26)$ & $15 \cdot 5 \pm 1 \cdot 5^{*}(28)$ & \\
\hline
\end{tabular}

Values significantly different from those of Female $1,{ }^{*} P<0.05,{ }^{* *} P<0.01$ (Student's $t$ test).

$T R H$. Circulating concentrations of prolactin in dominant and subordinate females were similar before and after TRH treatment, and both types of female showed a significant prolactin response to TRH $(P<0.001$; Text-fig. 3). Prolactin concentrations were elevated after $15 \mathrm{~min}$, but had significantly declined by $60 \mathrm{~min}$ and returned to baseline by $90 \mathrm{~min}$. While the dominant females consistently showed a greater response than did the subordinates, this was not statistically significant, perhaps because of the large variability in the prolactin response of both types of female. 


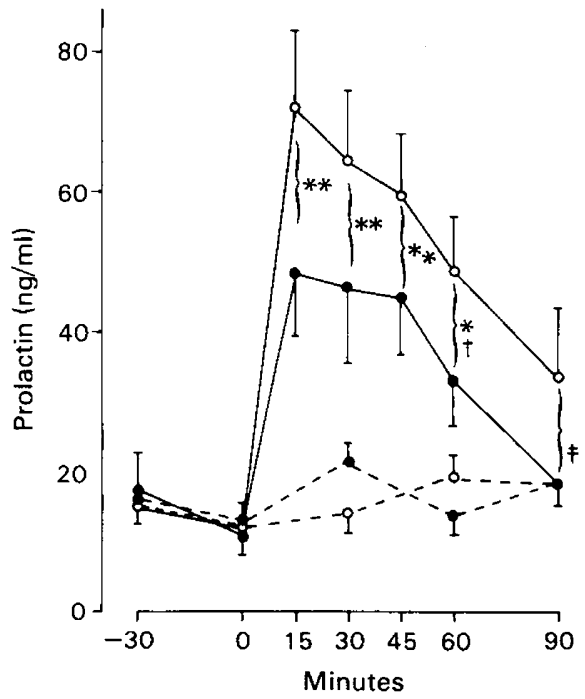

Text-fig. 3. Plasma prolactin concentrations (mean \pm s.e.m.) in 7 dominant $(\mathrm{O}-\mathrm{O})$ and 9 subordinate (-) females given $25 \mu \mathrm{g}$ TRH i.v. at $0 \mathrm{~min}$. As controls, 5 dominant $(\mathrm{O}----\mathrm{O})$ and 5 subordinate $\left(\mathrm{O}_{---}\right)$females were given saline (at $0 \mathrm{~min}$ ). Values significantly different from those at -30 or $0 \mathrm{~min}$ : ${ }^{*} P<0.05,{ }^{* *} P<0.01$. Values at $30-90 \mathrm{~min}$ significantly different from those of the peak response at $15 \mathrm{~min}: \dagger P<0.05, \ddagger P<0.01$.

Metoclopramide. The pre-treatment prolactin levels of dominant and subordinate females were indistinguishable ( -30 and $0 \mathrm{~min}$; Text-fig. 4). Prolactin levels rose sharply in all animals between 0 and $30 \mathrm{~min}$ after administration of metoclopramide $(P<0.001)$ and mean $( \pm$ s.e.m.)

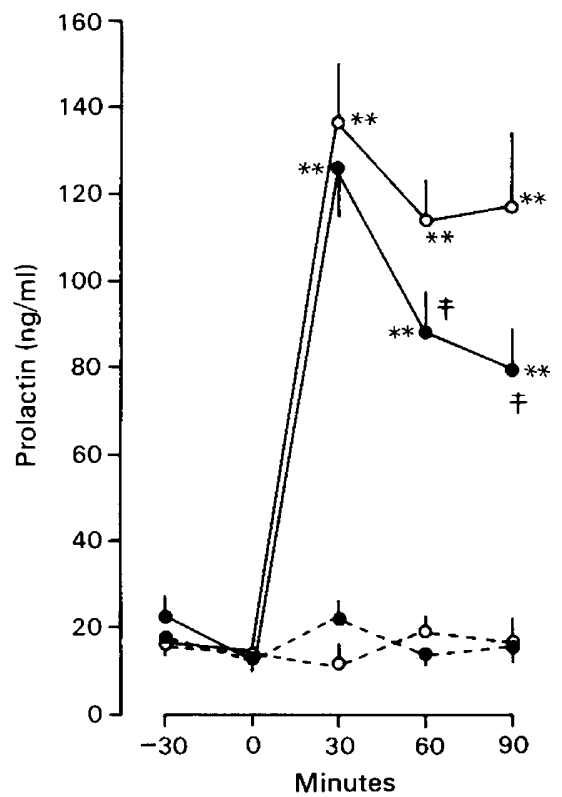

Text-fig. 4. Plasma prolactin concentrations (mean \pm s.e.m.) in 7 dominant $(0-0)$ and 9 subordinate (C) female marmosets given $2 \mathrm{mg}$ metoclopramide i.v. at $0 \mathrm{~min}$. As controls, 5 dominant $\left(\mathrm{O}_{----} \mathrm{O}\right)$ and 5 subordinate $\left(\mathbf{-}-\mathbf{- O}^{-}\right)$females were given saline (at $0 \mathrm{~min}$ ). Values significantly different from those at -30 and $0 \mathrm{~min}:{ }^{* *} P<0.01$. Values significantly different at $60-90 \mathrm{~min}$ from peak response at $30 \mathrm{~min}: \nmid P<0.01$. 
peaks of $136.7 \pm 13.1 \mathrm{ng} / \mathrm{ml}$ and $126.6 \pm 11.1 \mathrm{ng} / \mathrm{ml}$ were reached in the dominant and subordinate females, respectively. However, by 60 and $90 \mathrm{~min}$, prolactin levels had significantly declined only in the subordinate females (Text-fig. 4), producing a significant behaviour status-by-time sampled interaction $(P<0.05)$. Nevertheless, prolactin levels in the subordinate females were still well elevated above the pre-treatment values $(P<0.001)$.

\section{Discussion}

This is the first report describing changes in plasma levels of $\mathrm{LH}$, cortisol and prolactin in subordinate female marmoset monkeys. The results clearly show that subordinate females suffer from complete ovarian failure apparently due to gonadotrophin insufficiency, although the circulating concentrations of cortisol and prolactin are not elevated.

Inhibition of ovarian function in subordinate female marmosets was maintained during the complete 6-month sampling period (animals had been in their peer groups between 5 and 18 months; Table 1) and plasma progesterone concentrations never reached the luteal-phase values of the dominant females. The low progesterone values from subordinate females are consistent with previous findings of low total urinary oestrogen excretion in subordinate female marmosets. Urinary oestrogen concentrations were suppressed 10-fold in comparison with those of dominant females, and resembled the excretion pattern from bilaterally ovariectomized animals (Lunn, 1978). Furthermore, histological examination of the ovaries from 9 subordinate females revealed many primary and atretic follicles, but no preovulatory follicles, corpora lutea or corpora albicantia (D. H. Abbott, T. G. Baker \& S. F. Lunn, unpublished). Failure to observe appropriate elevations in circulating $\mathrm{LH}$ concentrations (Text-figs $1 \mathrm{~b}$ and $2 \mathrm{c} ; \mathrm{D}$. H. Abbott, unpublished) in the face of this evidence of chronically low ovarian hormone secretion, suggests that a deficiency in hypothalamic LH-RH and/or pituitary LH had accompanied the behavioural subordination of female marmosets, and that the impairment of ovarian function was probably due to insufficient gonadotrophic stimulation.

When challenged with a standard dose of LH-RH (Hodges, 1979), 7 out of 9 subordinate females showed a negligible increase in plasma $\mathrm{LH}$ values, unlike the large $\mathrm{LH}$ response from dominant females (Text-fig. 1). The pituitary of subordinate female marmosets therefore appears to be less responsive to LH-RH. Nevertheless, the poor pituitary LH response of subordinate animals to exogenous LH-RH might just as well reflect insufficient endogenous LH-RH stimulation from the hypothalamus, leading to a reduced pituitary LH content and a reduced pituitary capacity to synthesize LH. The LH responses of subordinate females to different doses of LH-RH and to multiple injections of a given dose of LH-RH require evaluation before these possibilities can be resolved. However, as 2 of the 9 subordinate females showed a normal LH response to LH-RH administration, the lack of a pituitary response to LH-RH may only be present in some subordinates or may only occur intermittently in each individual. Unfortunately, there is no reliable information concerning basal plasma LH levels in dominant and subordinate animals, because LH values for intact marmosets frequently fall below the sensitivity limit of the available assay (Hodges \& Hearn, 1977) and there is at present no suitable assay for marmoset FSH.

Each subordinate female marmoset was also insensitive to a standard oestrogen challenge, unlike the response found in dominant females, and hence the positive feedback surge of $\mathrm{LH}$ required for ovulation did not occur (Text-fig. 2). In fact, plasma LH levels in each of the 13 subordinates given oestrogen were suppressed below the sensitivity limit of the assay, and below the LH values of subordinates given oil, as if an intense negative feedback system was in operation. This would imply that if there was a preovulatory follicle present in the ovary of a subordinate female marmoset, the increased circulating oestrogen might fail to induce an ovulatory surge of $\mathrm{LH}$ from the pituitary by one of two ways. If the female marmoset is similar to the female rhesus monkey (Knobil, Plant, Wildt, Belchetz \& Marshall, 1980) and the pituitary 
can respond to the increased circulating oestrogen with an $\mathrm{LH}$ surge provided that a regular LH-RH release is maintained, then the lack of a pituitary LH response to oestrogen in subordinate females might arise from either a lack of normal hypothalamic LH-RH release or pituitary insensitivity to LH-RH (see above) which would produce the anovulatory condition. On the other hand, if the female marmoset is similar to many other mammalian species (see Fink, 1979, for references) and an increase in the release of hypothalamic LH-RH is apparently required to release an $\mathrm{LH}$ surge from the pituitary, then hypothalamic insensitivity to increased circulating oestrogens would lead to sterility, regardless of whether or not the pituitary was responsive to $\mathrm{LH}-\mathrm{RH}$. The evidence from this study favours the latter possibility because exogenous LH-RH elicited a normal LH response from two of the subordinate female marmosets although they were acyclic (Text-fig. 1b). However, an oestrogen challenge would have to be administered to LH-RH-treated subordinates before pituitary insensitivity could be ruled out.

It is possible that an insensitive positive feedback mechanism in subordinate female marmosets might reflect an extremely sensitive negative feedback response of the hypothalamus to the administered oestrogen. In other words, the negative feedback system has been 'set' at too sensitive a level in subordinates so that even very low circulating concentrations of oestrogen inhibit the secretion of LH-RH and hence LH. This could explain why the injected oestradiol benzoate completely suppressed plasma LH levels in subordinates below the sensitivity limit of the assay for $60 \mathrm{~h}$ (Text-fig. 2) while LH-RH administration elicited at least some plasma LH response (Text-fig. 1). Consequently, the pituitary of subordinate females would also be starved of hypothalamic LH-RH stimulation. In these respects, subordinate adult females may well resemble pre-pubertal female marmosets in which the $\mathrm{LH}$ response to $\mathrm{LH}-\mathrm{RH}$ is similarly poor (J. K. Hodges \& D. H. Abbott, unpublished). The subordinate female marmoset may be useful in examining the factors controlling ovarian inactivity, since 6 out of the 13 subordinates had had cycles before inclusion in a peer group (Abbott, 1979) and all the subordinates exhibited ovarian cyclicity 10-30 days after removal from the peer group (Abbott \& Hearn, 1978).

The poor LH responses of subordinate female marmosets cannot be attributed to increased levels of cortisol (Table 2) or prolactin (Table 3). The adrenal glands from subordinates were the same size and weight as those from dominant females (S. F. Lunn \& D. H. Abbott, unpublished). The stress of behavioural subordination in this female monkey therefore does not induce hyperprolactinaemia or elevated cortisol levels, a result in marked contrast to that reported by Bowman et al. (1978) and Keverne (1979), who found that behavioural subordination in female talapoin monkeys was associated with elevated prolactin and cortisol concentrations, suggesting that the suppression of oestrogen-induced $\mathrm{LH}$ surges in subordinate females was causally related to the elevated prolactin. The different prolactin and cortisol findings between talapoin and marmoset monkeys may partly arise because subordinate female talapoins continue to receive aggression long after captive groups are established (Bowman et al., 1978; Keverne, 1979), whereas aggressive interactions virtually cease 2-3 days after captive marmoset groups are set up (Abbott \& Hearn, 1978; Abbott, 1979), and this difference in aggression may, in turn, be related to the oestrogen treatment of the former. Nevertheless, since subordinate females in both species fail to show oestrogen-induced LH surges, a common mechanism(s) inhibiting positive feedback may be operating independently of circulating prolactin concentrations. In subordinate female marmosets, prolactin responses to TRH were consistently, but not significantly, lower than those of dominant females (Text-fig. 3). Metoclopramide, a pituitary cell-receptor antagonist of dopamine (a neurotransmitter which acts to inhibit prolactin release from the pituitary; Hökfelt \& Fuxe, 1972; Olson, Fuxe \& Hökfelt, 1972) produced a more striking difference (Text-fig. 4): at $30 \mathrm{~min}$ after injection of metoclopramide, prolactin levels of subordinates were similar to those of dominant females, but had fallen by 60 and $90 \mathrm{~min}$. It is therefore possible that, because of increased dopamine release or turn-over, pituitary prolactin secretion is inhibited in subordinates, hence the reduced 
response to pituitary stimulation. This explanation would be in accordance with the lower prolactin levels found in subordinates in 4 out of the 10 groups when compared with the dominant female (Table 3). Increased dopamine turn-over is also known to suppress LH secretion (LeBlanc, Lachelin, Abu-Fadil \& Yen, 1976; Lachelin, LeBlanc \& Yen, 1977; Fuxe et al., 1976; Judd, Rakoff \& Yen, 1978; McNeilly, 1980), presumably by reducing the hypothalamic output of LH-RH (de Cotte, De Menzes, Bennett \& Edwardson, 1980). This information would fit with the finding of reduced LH secretion in subordinate female marmoset and talapoin monkeys. Changes in plasma prolactin levels under such conditions would therefore be only a secondary effect, as indeed acknowledged by Bowman et al. (1978). Since oestrogen blocks dopamine at its receptor (Labrie, Baulieu, Caron \& Raymond, 1978), ovariectomy followed by oestrogen treatment of the subordinate talapoins and reduced oestrogen levels of the subordinate marmosets might contribute directly to the dissimilar prolactin findings in these two species of monkey.

The mechanisms by which the dominant female marmoset inhibits ovulation in her subordinates are unknown but they probably involve a combination of pheromones from her frequent scent marking (Epple, 1973; Epple, Golob \& Smith, 1979) and physical and visual contact (Abbott, 1979). Such a system would help to enforce the marmoset's monogamous mating system and encourage movement of subordinate females away from a group to pair with a male or become dominant in another group where the suppression of fertility would be removed.

We thank NIAMDD for the gifts of hormones; Dr J. Th. J. Uilenbroek for the LH antiserum; Miss B. Archibald for help with the prolactin assays; Dr J. P. Hearn for his criticism of the manuscript; Dr M. W. Vernon for statistical advice; Mrs C. Warfield for typing the manuscript; Miss D. McConnell and Mr R. Dodsworth for preparation of the figures; and Professor R. V. Short for encouragement.

\section{References}

Abbott, D.H. (1978) The physical, hormonal and behavioural development of the common marmoset, Callithrix jacchus jacchus. In Biology and Behaviour of Marmosets, pp. 99-106. Eds H. Rothe, H.-J. Wolters \& J. P. Hearn. Eigenverlag Hartmut Rothe, Göttingen.

Abbott, D.H. (1979) The sexual development of the common marmoset monkey, Callithrix jacchus jacchus. Ph.D. thesis, University of Edinburgh.

Abbott, D.H. \& Hearn, J.P. (1978) Physical, hormonal and behavioural aspects of sexual development in the marmoset monkey, Callithrix jacchus. J. Reprod. Fert. 53, 155-166.

Baird, D.T., McNeilly, A.S., Sawers, R.S. \& Sharpe, R.M. (1979) Failure of oestrogen-induced discharge of luteinizing hormone in lactating women. J. clin. Endocr. Metab. 49, 500-506.

Besser, G.M., Parke, L., Edwards, G. R. W., Forsyth, I.A. \& McNeilly, A.S. (1972) Galactorrhoea: successful treatment with reduction of plasma prolactin levels by Bromergo-cryptine. Br. med. J. iii, 669-672.

Bowman, L.A., Dilley, S.R. \& Keverne, E.B. (1978) Suppression of oestrogen-induced LH surges by social subordination in talapoin monkeys. Nature, Lond. 275, 56-58.
Chambers, P.L. \& Hearn, J.P. (1979) Peripheral plasma levels of progesterone, oestradiol-17 $\beta$, oestrone, testosterone, androstenedione and chorionic gonadotrophin during pregnancy in the marmoset monkey, Callithrix jacchus. J. Reprod. Fert. 56, 23-32.

de Cotte, D.M., De Menzes, C.E.L., Bennett, G.W. \& Edwardson, J.A. (1980) Dopamine stimulates the degradation of gonadotrophin releasing hormone by rat synaptosomes. Nature, Lond. 283, 487-489.

Epple, G. (1967) Vergleichende Untersuchungen über Sexual und Sozialverhalten der Krallenaffen (Hapalidae). Folia primatol. 7, 37-65.

Epple, G. (1973) The role of pheromones in the social communication of marmoset monkeys (Callithricidae). J. Reprod. Fert., Suppl. 19, 447-454.

Epple, G., Golob, N.F. \& Smith, A.B. (1979) Odor communication in the tamarin Saguinus fuscicollis (Callithricidae): behavioural and chemical studies. In Chemical Ecology: Odor Communication in Animals, pp. 117-130. Ed. F. J. Ritter. Elsevier/ North-Holland Biochemical Press, Amsterdam.

Fink, G. (1979) Neuroendocrine control of gonadotrophin secretion. Br. med. Bull. 35, 155-160.

Fuxe, K., Hökfelt, T., Agnati, L., Löfstrom, A., Everitt, B.J., Johansson, G., Wuttke, W. \& Goldstein, M. (1976) Role of monoamines in the control of 
gonadotrophin secretion. In Neuroendocrine Regulation of Fertility, pp. 124-140. Ed. T. C. Anand Kumar. Karger, Basle.

Hearn, J.P. (1977) Restraining device for small monkeys. Lab. Anim. 11, 261-262.

Hearn, J.P. \& Lunn, S.F. (1975) The reproductive biology of the marmoset monkey, Callithrix jacchus. In Breeding Simians for Developmental Biology (Lab. Anim. Handbook No. 6), pp. 191-202. Eds F. T. Perkins \& P. N. O’Donoghue. Laboratory Animals Ltd, London.

Hearn, J.P., Lunn, S.F., Burden, F.J. \& Pilcher, M.M. (1975) Management of marmosets for biomedical research. Lab. Anim. 9, 125-134.

Hodges, J.K. (1978) Effects of gonadectomy and oestradiol treatment on plasma luteinizing hormone concentrations in the marmoset monkey, Callithrix jacchus. J. Endocr. 76, 271-281.

Hodges, J.K. (1979) The effects of gonadectomy and oestradiol-17 $\beta$ on pituitary responsiveness to $\mathrm{LH}$ RH in the adult male marmoset (Callithrix jacchus). J. med. Primatol. 8, 155-166.

Hodges, J.K. \& Hearn, J.P. (1977) Effects of immunisation against luteinising hormone-releasing hormone on reproduction in the marmoset monkey, Callithrix jacchus. Nature, Lond. 265, 746-748.

Hodges, J.K. \& Hearn, J.P. (1978) A positive feedback of oestradiol on $\mathrm{LH}$ release in the male marmoset monkey, Callithrix jacchus. J. Reprod. Fert. 52, 83-86.

Hökfelt, T. \& Fuxe, K. (1972) Effects of prolactin and ergot alkaloids on the tubero-infundibular dopamine (DA) neurons. Neuroendocrinology 9, 100-122.

Horrobin, D.F. (1973) Prolactin: Physiology and Clinical Significance. Medical and Technical Publishing, Lancaster.

Judd, S.J., Rakoff, J.S. \& Yen, S.S.C. (1978) Inhibition of gonadotrophin and prolactin release by dopamine: effect of endogenous estradiol levels. J. clin. Endocr. Metab. 47, 494-498.

Keverne, E.B. (1979) Sexual and aggressive behaviour in social groups of talapoin monkeys. In Sex, Hor mones and Behaviour (Ciba Fdn Symp. (New Series) No. 62), pp. 271-297. Excerpta Medica, Amsterdam.

Knobil, E., Plant, T.M., Wildt, L., Belchetz, P.E. \& Marshall, G. (1980) Control of the rhesus monkey menstrual cycle: permissive role of hypothalamic gonadotropin-releasing hormone. Science, N.Y. 207, $1371-1373$.

Labrie, F., Baulieu, M., Caron, M.G. \& Raymond, V. (1978) The adenohypophyseal dopamine receptor. Specificity and modulation of its activity by estradiol. In Progress in Prolactin Physiology and Pathology, pp. 121-136. Eds C. Robyn \& M. Harter. Elsevier-North Holland-Biomedical Press, Amsterdam.
Lachelin, G.C.L., LeBlanc, H. \& Yen, S.S.C. (1977) The inhibitory effect of dopamine agonists on LH release in women. J. clin. Endocr. Metab. 44, 728-732.

Lamming, G.E., Moseley, S. \& McNeilly, A.S. (1975) Prolactin release in the sheep. J. Reprod. Fert. 40, 151-168.

LeBlane, H., Lachelin, G.C.L., Abu-Fadil, S. \& Yen, S.S.C. (1976) Effects of dopamine infusion on pituitary hormone secretion in humans. J. clin. Endocr. Metab. 43, 668-674.

Lunn, S.F. (1978) Urinary oestrogen excretion in the common marmoset, Callithrix jacchus. In Biology and Behaviour of Marmosets, pp. 67-73. Eds $\mathrm{H}$. Rothe, H.-J. Wolters \& J. P. Hearn: Eigenverlag Hartmut Rothe, Göttingen.

MeNeilly, A.S. (1980) Prolactin and the control of gonadotrophin secretion in the female. $J$. Reprod. Fert. 58, 537-549.

MeNeilly, A.S., Abbott, D.H., Lunn, S.F., Chambers, P.C. \& Hearn, J.P. (1981) Plasma prolactin concentrations during the ovarian cycle and lactation and their relationship to return of fertility post partum in the common marmoset (Callithrix jacchus). $J$. Reprod. Fert. 62, 353-360.

Olson, L., Fuxe, K. \& Hökfelt, T. (1972) The effect of pituitary transplants on the tubero-infundibular dopamine neurons in various endocrine states. Acta endocr., Copenh. 71, 233-244.

Raud, H.R., Kiddy, C.A. \& Odell, W.D. (1971) The effect of stress upon the determination of serum prolactin by radioimmunoassay. Proc. Soc. exp. Biol. Med. 136, 689-693.

Rothe, H. (1975) Some aspects of sexuality and reproduction in groups of captive marmosets (Callithrix jacchus). Z. Tierpsychol. 37, 255-273.

Rowell, T.E. \& Dixson, A.F. (1975) Changes in social organisation during the breeding season of wild talapoin monkeys J. Reprod. Fert. 43, 419-434.

Stevenson, M.F. (1978) The behaviour and ecology of the common marmoset (Callithrix jacchus jacchus) in its natural environment. In Biology and Behaviour of Marmosets, p. 298. Eds H. Rothe, H.-J. Wolters \& J. P. Hearn. Eigenverlag Hartmut Rothe, Göttingen.

Tyson, J.E., Friesen, H.G. \& Anderson, M.S. (1972) Human lactational and ovarian response to endogenous prolactin release. Science, N.Y. 177, $897-900$.

Van Look, P.F.A., McNeilly, A.S., Hunter, W.M. \& Baird, D.T. (1977) The role of prolactin in secondary amenorrhea. In Prolactin and Human Reproduction, pp. 217-224. Eds P. G. Crosignani \& C. Robyn. Academic Press, New York.

Winer, B.J. (1962) Statistical Principles in Experimental Design. McGraw Hill, New York.

Received 19 December 1980 